\title{
PRESENÇA DO MAR
}

\section{Adelaide Matana Villa.}

(Universidade Federal do Paraná)

Havia sol, no poente, sangrando, fazendo róseas as velas de volta ao lar; mas havia, sobretudo, a côr própria do mar.

Havia gaivotas gargalhando em tôrno de um barco a repousar; mas havia, sobretudo, o canto do mar.

Havia lianas e fôlhas de palmeiras nos braços do vento a se embalar; mas havia, sobretudo, o balanço do mar.

Havia estrêlas e algas marinhas seus segredos, na areia, a sepultar; mas havia, sobretudo, o mistério do mar.

Havia alegres corpos colorindo a espuma leitosa a fervilhar; mas havia, sobretudo, o mistério do mar. Havia céu azul, lua, vento, navios, gente buliçosa na areia a brincar; mas havia, sobretudo, a presença do mar. 


\section{CANTILENA DAS EVOCAÇÕES}

Vozes dormidas

quem vos despertou?

Lembranças passadas

quem vos invocou?

Juras esquecidas

quem vos relembrou?

Palavras perdidas

quem vos reencontrou?

Suspiros calados

de quem muito amou,

pranto escondido

quem vos revelou?

Saudade, saudade,

quem vos conclamou?

0 tempos passados,

quem vos convocou?

A noite do tempo

não vos ocultou?

Silêncio da noite

quem vos perturbou?

A hora tão calma,

o passado evocou

e o cortejo de mágoas

pela hora passou... 


\section{NAVIO NO PÔRTO}

"Navio no pôrto!

"Navio no pôrtoil"

A molecada passa correndo a gritar.

Toque-toque...

ressoam, apressados, na calçada,

os tamancos da estiva

até há pouco imobilizados

à sombra do cais,

na tarde ensolarada.

"Navio no pôrto!

Navio no pôrto!"

Avisa o apito rouco.

A rua se anima de repente.

Carregadores passam em disparada.

a moçada faz presença

na hora modorrenta

com mar semelhando lagoa parada.

Faces entediadas,

almas sonolentas,

tudo se alegra e movimenta

ao chegar o navio no pôrto.

O lugarejo perde o jeito de coisa morta,

faz-se vivo, tumultuado,

com vaivéns e toque-toques

e vozes estridentes repetindo:

"Navio no pôrto!

"Navio no pôrto!" 


\section{PARTILHA}

Quisera:

do leite virgem dos seringais, dos carnudos frutos dos coqueirais, das alvas salinas dos areais, dos brancos flocos dos algodoais, das gemas raras das minas gerais, do gado nédio dos pantanais, das fôlhas largas de tantos fumais, das doces polpas dos canaviais, dos pomos dourados dos laranjais, dos rubis preciosos dos cafèzais, do puro vinho dos parreirais, do ouro verde de mil ervais, de pinhos e pinhas dos pinheirais, dádivas divinas, excepcionais, nesta hora incerta de temporais, de lutas cruentas, supliciais, pelo sobreviver das vidas materiais, quisera um pouco, nada demais, para dar, aos que têm menos, mais, fazendo sorrisos de tristes ais! 


\section{MORENA QUE SAMBA, NÃO ANDA}

Feixe de canas,

penca de bananas,

limão e carambola

dentro da sacola,

lá vem a morena faceira,

que samba, não anda,

de volta da feira

ou, então, da quitanda.

Que morena doçura!

De mãos na cintura,

olhar todo ternura,

equilibra, não segura,

sacola, firme, à cabeça,

embora suba e desça

degraus que há na praça,

com irreal leveza e graça.

Ah! cabrocha dengosa,

cheirando a jambo e rosa,

flor e fruto do amor de três raças,

que com fitas e rendas vela as graças!

Há de ouvir, por onde passar,

sempre um alguém a implorar:

- "O morena bonita

que adejas no solo,

me dá o laço de fita

que palpita em teu colo!" 


\section{MOTIVO PARA SER FELIZ}

Dêem-me um motivo

para sorrir com vontade,

deliciadamente...

Sorriso em que a alma descanse

como um corpo em cadeira de balanço.

Dêem-me um motivo

para que meu olhar se ilumine,

alegremente...

Olhar que alegre melancólicos sêres ao redor

como a luz do vagalume alegra a noite sem lua.

Dêem-me um motivo

para que minhas mãos aplaudam,

entusiàsticamente...

Aplausos que animem os tímidos a prosseguir

como o ruflar das asas anima o pásaro incipiente.

Dêem-me um motivo

para que meus pés corram,

desabaladamente...

Corrida que ultrapasse acanhados limites

como os potros bravios ultrapassam porteiras e cercados.

Dêem-me um motivo

para que eu tôda me faça

em risos, cintilações, gestos, celeridade,

indispensáveis à minha felicidade, 


\section{PRIMAVERA, OUTRA VEZ!}

Outra vez êsse gesto quase esquecido de os braços abrir para o mundo abraçar...

e êsse ar fino, sabendo a poeira de orvalho, na manhã azulada espargindo frescor...

e êsse zumbido de abelha atarefada

à procura da flor mais fecunda...

e essa chuva perfumada de giesta dourando a festa de todos os jardins...

e essas rosas, e êsse trissar de andorinhas falando de amor às almas ansiosas...

e êsse ritmo acelerado de à vida retornar dos verdes ausentes e dos sêres adormecidos...

e êsse vigor renovado de cada jovem a cadência da marcha a acentuar... e ess a certeza, rescendendo a poder, de agruras passadas agora olvidar... e essa promessa da terra trabalhada de os grãos em flôres e frutos transformar... e êsse deslumbrar do eterno vir a ser pondo um sorriso de esperança em cada face... só pode ser a Primavera, outra vez! 


\section{MOTO PERPETUO}

Perpetuar o instante único,

irreversível,

do primeiro acontecer...

O momento em que o primeiro suspirar da brisa

arrepia a lisura do lago sonolento;

o momento em que a fôlha outonal

inícia o rodopio da liberdade;

o momento em que a noite se anuncia

no desmaio das côres do poente;

o momento em que a gôta de orvalho

estremece a desprender fulgores;

o momento em que o beijo inquieto, suspenso no ar, na flor mais bonita resolve pousar;

o momento final do botão, prelúdio da esplêndida rosa;

o momento em que fere o silêncio do amanhecer

a primeira nota de um gorjeio;

o momento do nascer de um gesto, um som, uma côr,

o momento mais belo de uma revelação

- o primeiro movimento -

o mesmo a se renovar eternamente,

movimento tão sutil

que fugaz se nos escapa

restando o desejo de retê-lo,

perpetuá-lo,

repetí-lo ao infinito,

encantamento sem fim. 


\section{A MARCHA DE TODOS NÓS}

Um, dois... um. dois...

vagido choroso primeiro,

o riso... depois.

Um, dois. . . um, dois...

- acêrto dos passos primeiro,

a corrida... depois.

Um, dois. . . um, dois...

promissores botões primeiro, as rosas... depois.

Um, dois. . . um, dois...

efêmero viver primeiro,

eternidade'. . depois. 